\title{
花崗岩に収着した $\boldsymbol{a}$ 核種のオートラジオグラフィによる研究
}

\author{
熊田政弘，佐川民雄 \\ 日本原子力研究所 \\ 319-11 茨城県那珂郡東海村白方白根 2-4 \\ 1990年 1 月 8 日 受理
}

Key Words : radioactive waste, alpha-emitting radionuclide, sorption, granite, autoradiography

\section{1. 緒言}

岩石に収着した核種の単位面積当たりの量と溶液中 の核種の濃度との比は岩石中の塩基性鉱物の含有量と 相関がある1など岩石を構成している鈗物ごとの収着 特性や収着機構を理解することが，地層中における放 射性核種の移行挙動を予測するために必要である。そ の一つの手法として，岩石小片や薄片を使った収着実 験とオートラジオグラフィを組み合わせた方法が試み られている2 ${ }^{2-4)}$ 。筆者らは, ネプッニウムやプルトニ ウムなど高レベル廃棄物に含まれる長寿命 $\alpha$ 核種の花 崗岩質結晶質岩への収着特性を調べるため， $\alpha$ 核種の 検出に有効な固体飛跡検出器 $\mathrm{CR}-39^{5)}$ を用いて ${ }^{237} \mathrm{~Np}$ と ${ }^{239} \mathrm{Pu}$ を収着した花崗岩薄片表面のオートラジオグ ラフィを実施し ${ }^{6}$ ，面像解析装置によるトラック密度 の測定と薄片の顕微鏡観察等から，これら核種の収着 のメカニズムについて考察した。

\section{2. 収着実験}

試料とした稲田産黒雲母花崗岩薄片はカバーグラス

Table 1 Chemical composition of groundwater ${ }^{a}$ (ppm)

\begin{tabular}{lr|lc|lr}
\hline $\begin{array}{l}\text { Compo- } \\
\text { nent }\end{array}$ & Conc. & \multicolumn{2}{|l|}{$\begin{array}{l}\text { Compo- } \\
\text { nent }\end{array}$} & Conc. & \multicolumn{2}{l}{$\begin{array}{l}\text { Compo- } \\
\text { nent }\end{array}$} & Conc. \\
\hline $\mathrm{NH}_{4}$ & $<0.1$ & $\mathrm{Mn}$ & $<0.1$ & $\mathrm{Cl}$ & 4.7 \\
$\mathrm{Na}$ & 19.2 & $\mathrm{Cr}$ & $<0.1$ & $\mathrm{NO}_{3}$ & 0.7 \\
$\mathrm{~K}$ & 0.7 & $\mathrm{Ni}$ & $<0.1$ & $\mathrm{PO}_{4}$ & $<0.5$ \\
$\mathrm{Ca}$ & 5.5 & $\mathrm{Al}$ & $<0.1$ & $\mathrm{Si}^{\mathrm{b}}$ & 7.0 \\
$\mathrm{Mg}$ & $<0.1$ & $\mathrm{HCO}_{3}$ & 47 & $\mathrm{Si}^{\mathrm{c}}$ & 6.9 \\
$\mathrm{Fe}$ & $<0.1$ & $\mathrm{SO}_{4}$ & 8.3 & & \\
\hline
\end{tabular}

a ) $E_{\mathrm{h}}=380 \mathrm{mV}$, ionic streng th $I=0.077$
b) Total silica
c) Dissolved silica

をつけずに $1 / 2 \mu \mathrm{m}$ の ダイヤモンドペーストで鏡面仕 上げした。作成した10枚の薄片から求めた花崗岩の鉱 物組成は石英が30から $70 \%$ ，長石が45から $75 \%$ ，黒雲 母が 5 から $15 \%$ である。褐篻石やアパタイト，ジルュ ンなどが微量存在することがある。褐色一茶褐色の黒 雲母が散在する花崗岩薄片の写真を Photo. 1 (a) に示 †。

${ }^{237} \mathrm{~Np}$ と ${ }^{239} \mathrm{Pu}$ を含む $3 \mathrm{M}$ 硝酸溶液 $0.5 \mathrm{ml}$ を筑波山 の地下 $250 \mathrm{~m}$ 付近から採取した天然の地下水に加えて $500 \mathrm{ml}$ の試験溶液とした。地下水は $0.45 \mu \mathrm{m}$ のィル タで粒子を取り除いた後, 試験溶液作成までの間大気 と接して扣り, 大気と平衡にある水中と同程度の溶存 酸素を含んでいる。試験溶液はポリェチレン製容器に 入れ，室温のフード内に約 1 か月間保管した。この間 の溶液の $\mathrm{pH}$ は7.3-7.5 であった。試験開始直前 に, シリコン表面障壁型検出器(SSB)により測定した 試験溶液中の ${ }^{237} \mathrm{~Np}$ と ${ }^{239} \mathrm{Pu}$ の濃度はそれぞれ 1117 $\mathrm{Bq} / \mathrm{ml}, 21.7 \mathrm{~Bq} / \mathrm{ml}$ であった。分画分子量 10000 フ ィルタを用いて限外ろ過したろ液の放射能強度はろ過 する前の試験溶液と変わらなかった。両核種の濃度は ネバタ州ュッカ山の地下水中の溶解度 ${ }^{7)}$ より充分小さ い。

試験溶液 $20 \mathrm{ml}$ 程度を密閉性の良いプラスチック容 器に入れ, 岩石薄片の研磨面が液に浸るように容器の 蓋に吊り下げ（Fig. 1)，室温のフード内に48時間保持 して $\alpha$ 核種を収着させた。48時間後，プラスチック容 器から薄片を取り出し, 少量の高純水で軽くすすぎ, 乾燥後ルミラ膜で密封した。

\section{3. $\boldsymbol{a}$-オートラジオグラフ}

実験にはソーラオプチカルジャパン社製の CR-39 (allyl diglycol carbonate の商標名, 化学組成は $\mathrm{C}_{12}$ 


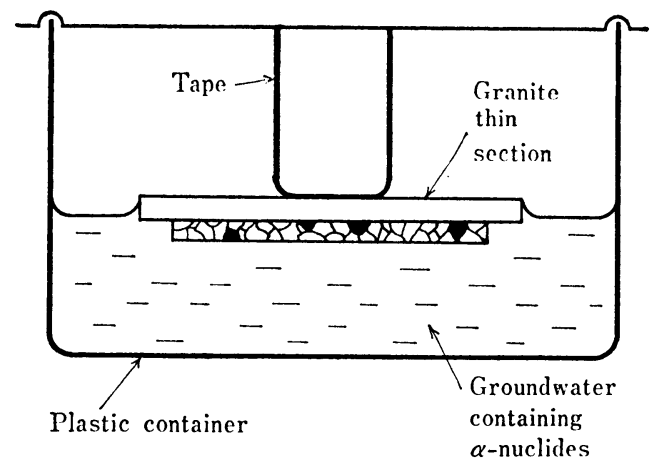

Fig. 1 Schematic diagram of alpha nuclides sorption on a granite thin section.

$\left.\mathrm{H}_{18} \mathrm{O}_{i}\right)$ プラスチック検出器を用いた。平坦なテーブ ルの上に厚さ $1.8 \mathrm{~mm}$ の CR-39 を罱き, ルミラ膜で密 封した㐾不薄けの $\alpha$ 核種を収着した面を重ねておるり を載せ，168時間の露出を行った。露出後の検出器は 硝酸セルロース系の固体検出器を用いたオートラジオ グラフ $1^{8)}$ と同様に, 水酸化ナトリウム $25 \mathrm{~g}$, 水酸化力 リウム $20 \mathrm{~g}$ および過マンガン酸カリウム $4.5 \mathrm{~g}$ を $90 \mathrm{ml}$ の純水に溶解させた液に浸し, $50{ }^{\circ} \mathrm{C}$ で180分間エッチ ングした後水洗した。末使用の CR-39フィルムを露出 したフィルムと同一条件でェッチングし，600倍の観 察倍率で CR-39自身のバックグラウンド飛跡 ${ }^{91}$ を観察 したがトラックは認められなかった。つぎに, 未収着 の花崗少薄片について収着試験版间様に 168 時間露 出してェッチングを行ったが $\alpha$ ートラックは認められ なかった。したがって, 収着試験片のオートラジオグ ラフィで CR-39を現像 した時のバックグラウンドと なるトラックは無視できる。

\section{4. 結果および考察}

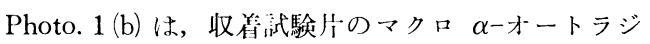
オグラフである。檢出器を䍒体鏡の腤視野透過光で撮 ったもので，トラックは白点として表されている。 トラックは一様に分布して㧍らず, 坚不薄片の褐色一 茶褐色を㕵する黒零母結晶（Photo. 1 (a)）の存在位置. に対応して集中している。トラックの集中域はちょう ど黒雲母絬晶の形と一致している。これは, 地下水中 に含まれていた ${ }^{237} \mathrm{~Np}$ 抒よび ${ }^{239} \mathrm{Pu} の \alpha$ 核種が花崗肾 中の黒雲母に選択的に収筫していることを明示してお り, 花崗坚中に数\%から1数\%しか存在しない黑雲母 が $\alpha$ 核種の収着に主要な役割を果している。

石英結晶が集まっている薄片部分のマクロオートラ ジオグラフではトラックが網の目状に並んでいる。走
査型電子顕微鏡で観察すると, 石英の結晶粒界には幅 数ミクロンの溝が発達している。網の日状のトラック の配列は粒界にトラップされた $\alpha$ 核種によるものと思 われる。網の日状に配列したトラックで围まれた内側 部分を 400 - 600倍で観察すると, 少量の均質に分布す るトラックが涊められる。これは石英結晶に収着した $\alpha$ 核種を示している。雨像解析装置を用いて, 1000 倍の観察倍率で一这領域内のトラック数を部測し, 石 英および黑雲母に収着した $\alpha$ 核種によるトラックの単 位面積当たりのトラック密度を求めると, 黒雲母では 石英の 40 倍から 100 倍程度のトラック密度を示した (Table 2)。黑雲母は石英に比べて 1-2 桁ほど $\alpha$ 核種 の収着能力が火きいようである。

Photo. 2 (a)に黒零母 ( B (1), B(2)) 拈よび不 英 (Q) の薄川の写畗 を, Photo. 2 (b) に间一 部分のミクロオートラ ジオグラフを示す。黑 Table 2 Track density

\begin{tabular}{lr}
\hline Mineral & $\begin{array}{c}\text { Track density } \\
\left(\text { track } / \mathrm{mm}^{2}\right)\end{array}$ \\
\hline Quartz & $1.2 \times 10^{3}$ \\
Biotite (1) & $1.1 \times 10^{5}$ \\
Biotite (2) & $1.2 \times 10^{4}$ \\
\hline
\end{tabular}
雲母は鉱物粒ごとにトラック密度が異なっている。黑 雲母結晶は板状に剥がれる特性を持つ嬖開が発達した 層状ケイ酸塩である。薄片の黑雲母( B (2))には雲母の 層状構造を切った太い縞が観察される。一方, 黒雲母 (B(1))では憵開に平行な板状を呈している。Ticknor ら ${ }^{10)}$ は黒雲母の䢃開に平行な拭料, 嬖開に直行する武 料および䢃開面と 45 度の角度で交わる 3 種類の北料を 作成し, これら試料への ${ }^{90} \mathrm{Sr}$ の収着试験から, 収着量 は黒雲母結晶の䢃開面に直交する北料で最も多く，憵 開に平行な伍料で最も少ないといら露出した黙零母の 結晶面と核種の収着量との閣連を指摘している。㣌開 而に直交与る面というのは，周状に積層している埋雲 母の絬晶㩐造を縦に切断した而である。㗨母などの層 状ケイ酸塩の層面に垂直な破壊面には原子価を㟨足し ない酸素原子（来飽和原子俩）が存しており, 通常 この酸素原子は水素原子と結令してシラノール基 $(\mathrm{Si}-$ $\mathrm{OH}$ ) あるいは水酸基を含む $\mathrm{Al}-\mathrm{OH}$ となっている。シ ラノール基は電離したりプロトンを付加したり, 黒雲 母などの粘土鈗物表面へのイオンの吸着に重要な働き をしている。このような粘土鈆物の層面に平行でない 面上はシラノール基や末飽和原子俩などによる水溶液 中の陽イオンの交換場所となっている。

ネプツニウムは中性付近の大気と平衡にある水浴液 中で原子価 5 価の $\mathrm{NpO}_{2}{ }^{+}$が優勢であり, 溶存する炭酸 ガスの量により一部は炭酸ガス錯体を作って中性ない し陰イオンとして $\mathrm{NpO}_{2}{ }^{+}$とともに共存する ${ }^{11}$ 。プルト 


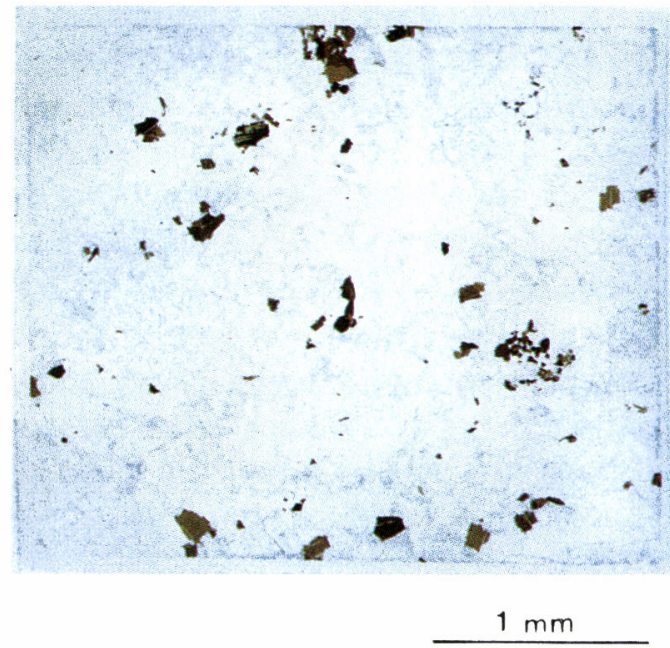

(a)

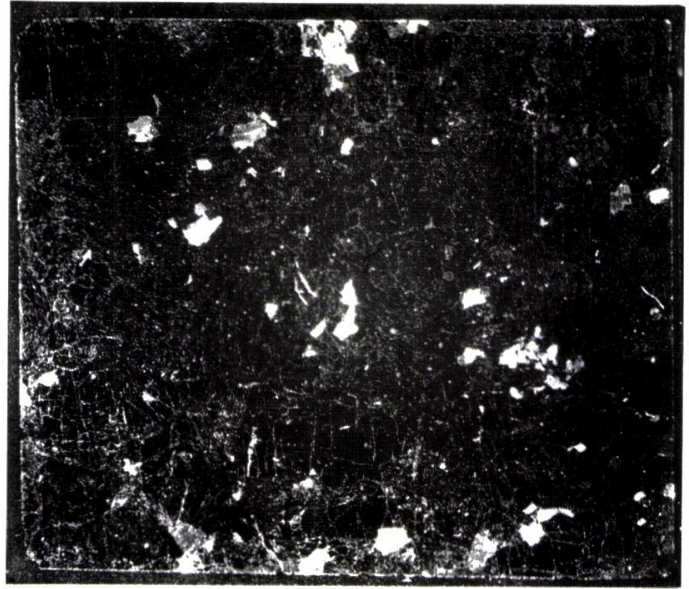

$1 \mathrm{~mm}$

(b)

Photo. 1 Photomacrograph of a granite thin section (a), and an alpha autoradiograph of the thin section sorbed alpha nuclides (b).

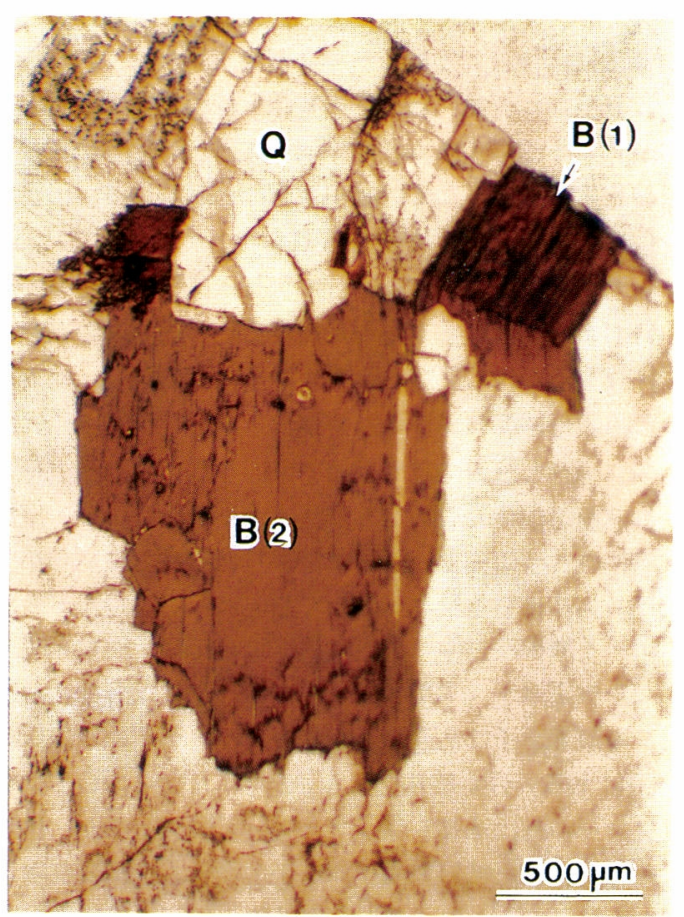

Photo. 2 (a) Microphotograph of the thin section showing biotites ( $\mathrm{B}(1)$, $B(2))$ and quartz $(Q)$.

ニウムは安起な原子洒として 3 洒から 7 価までをとる ことができるが，地下水中では， $\mathrm{PuO}_{2}{ }^{+}$打よび $\mathrm{PuO}_{2}{ }^{2+}$ が安等に存在している7”。溶存するプルトニウムやネ

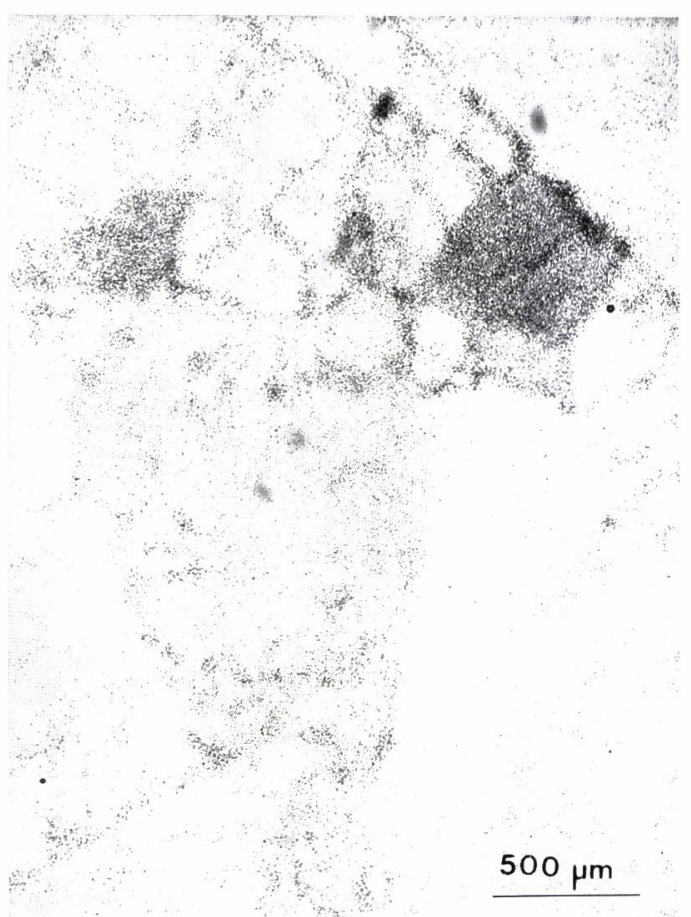

Photo. 2 (b) Microautoradiograph of the thin section corresponding location for (a).

プッニウムの陽イオン種が，層状棈造切断面に現れた シラノール基などとイオン交換することにより黑雲母 表面に吸着したものと考光られる。薄片中の黑雲母の 
収着能が結晶粒ごとに異なるのは切断面に現れるシラ ノール基や未飽和原子価の密度が層面を切る角度など により多様なためであろう。

黒雲母結晶以外をプラスチックの薄い板でマスク し, 黑雲母に収着した ${ }^{237} \mathrm{~Np}$ と ${ }^{239} \mathrm{Pu}$ との放射能比を

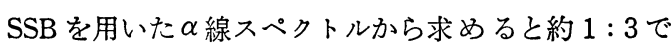
あった。試験溶液中に拉よそ $50: 1$ の割合で $\alpha$ 放射能 の大半を占めていたネプッニウムは黒雲母にほとんぞ 収着せず，プルトニウムが相対的に濃集された。これ はネプツニウムとプルトニウムの試験溶液中に括ける 溶存化学形の違い汇起因するものと推定される。ネプ ッニウムでは地下水中に錯体とともに溶存する陽イオ ン種としての $\mathrm{NpO}_{2}{ }^{+}$が少なく, 一方, 溶存するプルト ニウムのほとんどが陽イオン種として挙動すると考光 られる。

雲母などの層状ケイ酸塩鉱物では層間を占めている $\mathrm{K}^{+}$や $\mathrm{Na}^{+}$あるいは $\mathrm{Ca}^{2+}$ などの層間イオンが他の陽イ オンと容易に交換することが知られている。ネプッニ ウムやプルトニウムでは地下水中で安定に存在する $\mathrm{NpO}_{2}{ }^{+}$や $\mathrm{PuO}_{2}{ }^{+}$などの 1 価の陽イオンの半径が大き く, 膨潤する特性がない黑雲母などでは，これらイオ ンが層間イオンと交換して層間に入り込むことはでき ない。黒雲母へのイオン吸着はおるに切断面に現れる シラノール基や未飽和原子価を持つ酸素原子によるも のと推定される。この場合のイオン吸着は水中の水素 イオン濃度 $\mathrm{pH}$ に依存するので, $\mathrm{pH}$ と吸着量との関 係を詳しく調べる必要がある。

中性付近の溶液中のネプツニウムのイオン吸着が石

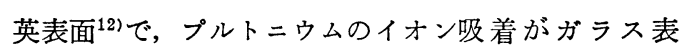

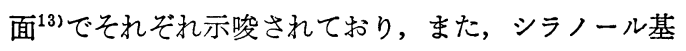
は石英や長石表面でも形成されると考兄れることか ら，これら鉱物への $\alpha$ 核種の収着も鈗物表面へのイオ ン交換に上る吸着と推定される。鉱物表面でのシラ， ール基等によるイオン交換量の違いは, 顕微赤外吸収 などの手段によって各鉱物表面のシラノール基を定量 分析する，あるいは各鉣物表面の電荷密度を測定する ことにより明らかになるであろう。

今後, 種々の条件下に打ける収着実験に打いてオー トラジオグラフィを併用し，核種の岩石への収着に関 する研究を進める予定である。

本報をまとめるにあたり有益な御助言をいただいた 上薗裕史博士に感謝いたします。放射能測定にご協力 いたたいた日本原子力研究所 WASTEF 管理室の関係 各氏に感謝いたします。

\section{文献}

1) Vandergraaf, T.T. and Sampson, D.R.M.: Transactions, 35, 65-66 (1980)

2) Beall, G.W., O'Kelley, G.D. and Allard, B.: ORNL-5617 (1980)

3) Smyth, J.R., Thompson J. and Wolfsberg, K.: Radioact. Waste Manag., 1, (1)13-24 (1980)

4) Vandergraaf, T.T., Abry, D.R.M. and Davis, C.E.: Chem. Geol., 36, 139-154 (1982)

5）林 孝義, 応用物理, 49, 705-712（1980）

6）熊田政弘, 佐川民雄 : 第27回理工学に和沙る同 位元素研究発表会要旨集, 119 (1990)

7) Nitsche, H. and Edelstein, N.M.: Radiochim. Acta, 39, 23-33 (1985)

8）佐川民雄, 田代晋吾, 松本征一郎 : 日本原子力 学会講演要旨集「昭61年会」, H7 (1986)

9) Ishigure, N. and Matsuoka, O.: Hoken Butsuri, 22, 287-293 (1987)

10) Ticknor, K.V., Vandergraaf, T.T. and Kamineni, D.C.: AECL TR-365 (1985)

11) Bidoglio, G., Tanet, G. and Chatt, A.: Radiochim. Acta, 38, 21-26 (1985)

12) Nakayama, S., Arimoto, H., Yamada, N., Moriyama, H. and Higashi, K.: ibid., 44/45, 179-182 (1988)

13) Banba, T., Tashiro, S., Nukaga, K., Sagawa, T. and Nomura, M.: Nucl. Chem. Waste Manag., 8, 45-54 (1988)

\section{Abstract}

Study of Alpha-Nuclides Sorption on Granite by Autoradiographic Method. Masahiro KumatA and Tamio SAGAWA: Japan Atomic Energy Research Institute, 2-4, Shirakata-shirane, Tokaimura, Naka-gun, Ibaraki-Pref. 319-11, Japan.

Sorption of two alpha nuclides, ${ }^{237} \mathrm{~Np}$ and ${ }^{239} \mathrm{Pu}$, on granite was studied by the autoradiographic method using a solid state track detector (CR-39). The autoradiographs for the surface of rock thin sections of the Inada biotite-granite which were immersed for $48 \mathrm{~h}$ in the groundwater containing both nuclides, showed that the alpha nuclides sorbed preferentially on biotite rather than on quartz and feldspar. Mechanism of the alpha nuclides sorption on granite was discussed based on the results of optical microscopic observations of the thin section, track density measurements and alpha-ray spectrometry. It was considered that the ion exchange seems to be a major mechanism of the sorption of these nuclides on the granite.

(Received January 8, 1991) 